\title{
Early cultivated wheat and broadening of agriculture in Neolithic China
}

\author{
Xiaoqiang Li, ${ }^{1 *}$ John Dodson, ${ }^{2}$ Xinying Zhou,,${ }^{1,3}$ Hongbin \\ Zhang ${ }^{1,3}$ and Ryo Masutomoto ${ }^{4}$
}

\author{
( ${ }^{1}$ State Key Laboratory of Loess and Quaternary Geology, Institute of Earth Environment, CAS, \\ Xi'an Hi-Tech zone, Xi'an 710075, China; ${ }^{2}$ Institute for the Environment, Brunel University, \\ Uxbridge UB8 3PH, UK, ${ }^{3}$ Graduate University of Chinese Academy of Sciences, Beijing, China; \\ ${ }^{4}$ Department of Earth and Planetary Science, University of Tokyo, Tokyo 113-0033, Japan)
}

Received 22 October 2006; revised manuscript accepted 5 January 2007

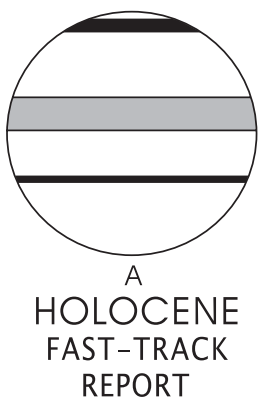

\section{Introduction}

The study of agricultural origin, expansion and cultural impacts has intensified during the last few decades as new techniques have enabled better reconstructions of human prehistory, and the formulation of better-focused hypotheses to be addressed (eg, Cavalli-Sforza et al., 1993; Zohary and Hopf, 2000; Ammerman, 2003; Diamond and Bellwood, 2003; Hazelwood and Steele, 2004; Bellwood, 2005). It is now clear from high-resolution archaeobotanical evidence, genetic studies and cultural chronologies (eg, Morrell et al., 2003; Armelagos and Harper, 2005) that agriculture emerged as the predominant form of food production directly from a huntergatherer background in at least two major regions of the Eurasian continent (Bellwood, 2001, 2005) (Figure 1). The Fertile Crescent of Southwest Asia was the place of origin of domesticated wheat and barley between about 9500 and 7500 BC (eg, Zohary and Hopf, 2000; Diamond and Bellwood, 2003; Bellwood, 2005; Wilcox, 2005). Earliest agriculture in China was just as revolutionary as that in Southwest Asia, and may have a similar chronology (Underhill, 1997). Rain-fed crops

*Author for correspondence (e-mail: 1xq@loess.llqg.ac.cn) and wetland rice-based agriculture were developed in the Yellow and Yangtze River basins independently by the early Holocene (Zhao, 1998; Shelach, 2000; Crawford, 2006) (Figure 1). Barley is known from the western Yellow River region between 2000 and 800 вC (Zhao, 2005).

Agricultural expansion and cultural impacts were momentous events for Neolithic Eurasia (Figure 1). The hypothesis of 'Early farming dispersal' focused on early agriculture development included population growth, the expansions of material cultures and language (Bellwood, 2001, 2005). Many models have been applied to demonstrate the agricultural radiation from origin centres, with initial movement of Neolithic economic systems, dispersal events and expanding population (Cavalli-Sforza et al., 1993; Ammerman, 2003; Hazelwood and Steele, 2004) and this is clearly a complex issue with no clear consensus of how this happened. At this time, it raises the questions of how and when two independently derived agricultural systems of Southwest and East Asia spread, met and exchanged over such a vast area of the Old World.

Here, we report original findings from an archaeological site of Xishanping on the early cultivated wheat (4650 cal. yr BP) and a flourishing complex agriculture (4650-4300 cal. yr BP) in Neolithic China, which includes eight main crop types and the 


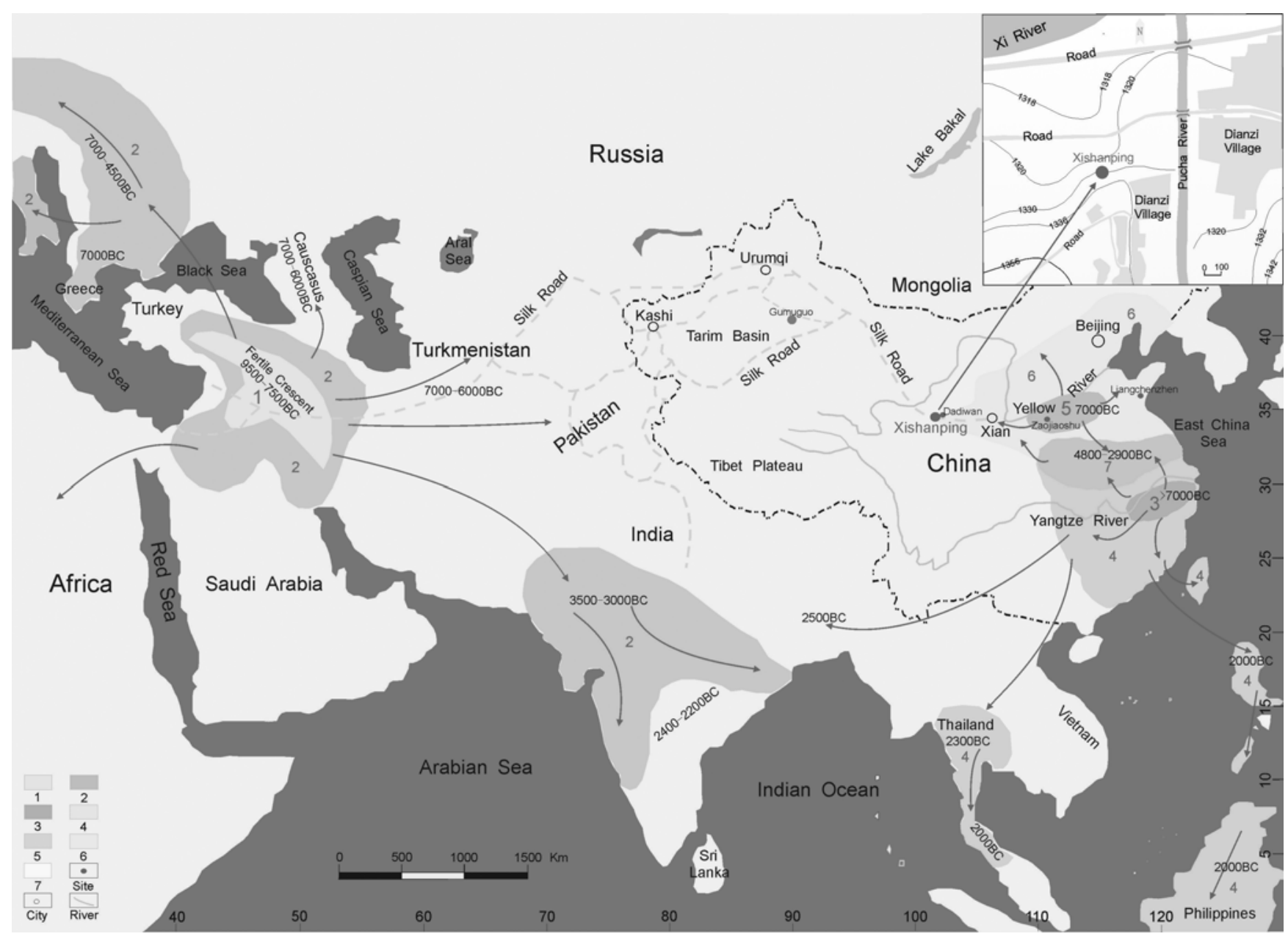

Figure 1 The origins of agriculture and the expansion of Neolithic agriculture on the Eurasian continent. 1, the area of origin of wheat and barley in Southwest Asia; 2, the distribution of Neolithic agriculture in Europe, West Asia and India; 3, the area of origin of rice in the Middle and Lower Yangtze Basin; 4, the Neolithic distribution of rice in East and Southeast Asia; 5, the area of origin of millet in the middle reaches of the Yellow River; 6, the distribution of millet in the Neolithic; 7, the area of overlap of rice and millet during the Yangshao Cultural period

oldest known cultivated rice (5070 cal. yr BP) in northwest Neolithic China.

\section{Xishanping archaeological site}

The Xishanping archaeological site $\left(34^{\circ} 33^{\prime} 50^{\prime \prime} \mathrm{N}, 105^{\circ} 32^{\prime} 41^{\prime \prime} \mathrm{E}\right.$, $1330 \mathrm{~m}$ a.s.1.) is located on a southern terrace of the Xi River in the Tianshui Basin of northwest China (Figure 1). The Xi River is an upper tributary of the Wei River, which ultimately flows into the Yellow River. It lies between the heartlands of wheat and rice agriculture and is also crossed by the famous 'Silk Road' (Figure 1). Today the region receives a mean annual precipitation of $574 \mathrm{~mm}$, distributed with a strong summer bias, and the area has a mean annual temperature of $11.6^{\circ} \mathrm{C}$. The potential vegetation is warm-temperate mixed coniferbroadleaved forest, woodland and grasslands $(\mathrm{Wu}$ and Wang, 1983).

The Xishanping site was first investigated in 1956, and excavated between 1986 and 1990 (Institute of Archaeology of CASS, 1999). The archaeological site occupies an area of 204 $800 \mathrm{~m}^{2}$ and has several cultural periods represented between 7800 to 3000 cal yr BP (Institute of Archaeology of CASS, 1999). It is known for the record of intensive agriculture associated with the Majiayao (5300-4200 cal. yr BP) and Qijia
Cultures (4300-3900 cal. yr BP) during the middle-late Neolithic (Institute of Archaeology of CASS, 1999; An et al., 2005). A continuous undisturbed cultural sediment section of $650 \mathrm{~cm}$ depth was selected for this study from a Xi River terrace in 2004. The section can be divided into seven layers according to sediment type, colour and magnetic properties (Figure 2).

\section{Methods and results}

The samples were prepared using flotation. Samples of $100 \mathrm{~kg}$ of soil from each sediment layer were suspended in water with a strong vortex stirrer. The floating material was poured through $1 \mathrm{~mm}$ and $0.3 \mathrm{~mm}$ mesh sieves until all floating material was removed. The captured macro remains were examined under a binocular microscope and seeds, charred material, kernels and charcoal were picked out for identification and radiocarbon dating. Eight samples of charcoal and charred seeds were selected for accelerator mass spectrometry (AMS) dates (Stuiver et al., 1998) (reported here as calibrated yr, Table 1). The charcoal age at $60 \mathrm{~cm}$ depth is $4330 \mathrm{cal}$. yr BP and a charred seed at $620 \mathrm{~cm}$ depth has an age of $5165 \mathrm{cal}$. yr BP. The radiocarbon dates are not all in clear stratigraphic order and this may be due to some reworking by animal burrowing or pit 


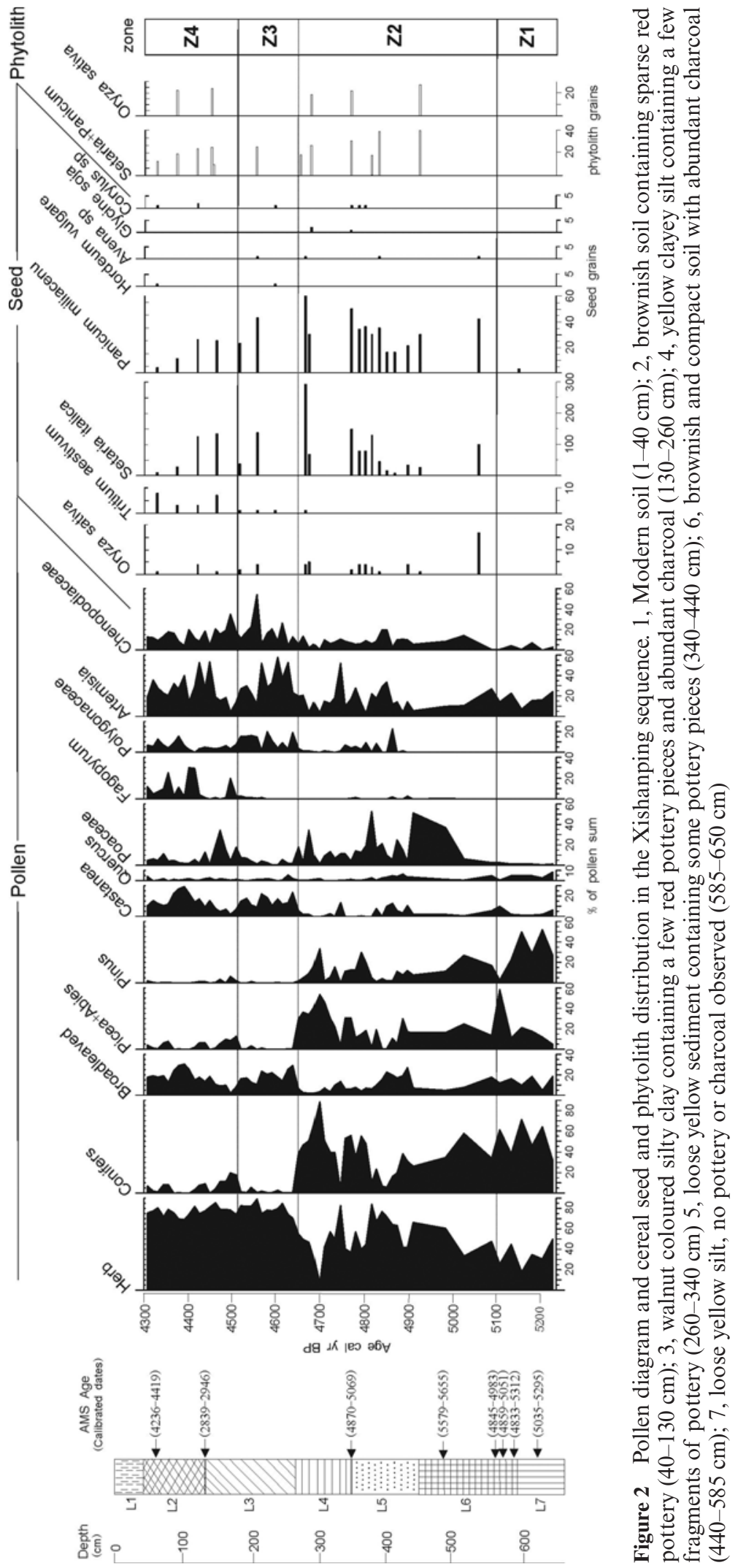


Table 1 Accelerator mass spectrometry (AMS) dates from Xishanping

\begin{tabular}{lllll}
\hline Depth $(\mathrm{cm})$ & Laboratory number & Age $\left({ }^{14} \mathrm{C}\right.$ yr BP $)$ & Cal. yr BP $(2 \sigma)$ & Dated material \\
\hline 60 & TKa13882 & $3900 \pm 35$ & $4236-4419$ & charcoal \\
130 & TKa13883 & $2785 \pm 30$ & $2839-2949$ & charcoal \\
345 & TKa13884 & $4430 \pm 35$ & $4870-5069$ & charcoal \\
490 & TKa13885 & $4855 \pm 35$ & $5579-5655$ & charcoal \\
560 & TKa13886 & $4360 \pm 35$ & $4845-4983$ & charcoal \\
570 & TKa13887 & $4400 \pm 35$ & $4859-5051$ & charcoal \\
585 & TKa13890 & $4430 \pm 100$ & $4833-5312$ & charred seed (rice) \\
620 & TKa13889 & $4490 \pm 35$ & $5035-5295$ & charred seed (Panicum millet) \\
\hline
\end{tabular}

All assays of six charcoal samples and two charred seeds were run at the Accelerator Mass Spectrometry Laboratory, University of Tokyo, Japan. Calibrations were run with Radiocarbon Calibration Program Calib Rev 4.4 (Stuiver et al., 1998).

digging. The charcoal samples at 60 and $490 \mathrm{~cm}$ appear to be older than samples around them and are possibly reworked. The dates between 345 and $560 \mathrm{~cm}$ suggest a very rapid sedimentation rate compared with the overlying sediments. The pollen diagram indicates there are vegetation sequences that cannot be explained by a homogenization and complete mixing of the record. The interval between 5250 and 4300 cal. yr BP corresponds to the Majiayao Cultural period (Institute of Archaeology of CASS, 1999; An et al., 2005) (Figure 2).

Sixteen seed types have been identified from 20 samples and confirm the presence of the cereals: rice (Oryza sativa), wheat (Triticum aestivum), foxtail millet (Setaria italica), broomcorn millet (Panicum miliaceum), barley (Hordeum vulgare), oats (Avena sp.) and probable soybean (Glycine soja) (Figure 2). In addition nine other seed types, which include grasses, and Corylus shell is present. Broomcorn millet was first observed at 5165 cal. yr BP (direct dating of seed by AMS). Rice and foxtail millet first appeared at $5070 \mathrm{cal}$. yr BP (direct dating of rice seed). Rice and millet seen as phytoliths continued to appear through the sequence from 585 to $40 \mathrm{~cm}$ depth (Figures 2 and 3). Wheat seeds first occurred at $4650 \mathrm{cal}$. yr BP, and then were found in eight samples between 350 and $40 \mathrm{~cm}$ depth. Barley seeds appeared in two samples, the oldest at $4600 \mathrm{cal}$. yr BP. Oat seeds were observed in four samples, the oldest of which was at 5070 cal. yr BP. Glycine soja seeds appeared in two samples, the oldest at 4770 cal. yr BP (Figure 2).

Thirty-two samples were examined from the sediment for phytoliths. A scanning electron microscope was used to reveal detail to aid comparison with modern cereal grains. Dendriform millet phytoliths, belonging to Panicum miliaceum and Setaria italica were identified, and these dominated the phytoliths in the whole sediment profile (Figures 2 and 3). Three morpho-type phytoliths of rice (Oryza sativa), some double-peaked husks, scooped bilobes from leaf fragments and fan-shaped bulliform types from leaves were identified from five samples (Figures 2 and 3). The presence of rice and millet phytoliths supports the notion that both were processed on site, and probably were under cultivation nearby (Harvey and Fuller, 2005).

Pollen was recovered from Xishanping sediments using a heavy liquid separation method. The studies of modern surface pollen show that Poaceae pollen had low representation. Percentages of grass pollen are usually low $(10 \%)$, even in the vegetation dominated by Poaceae in the modern vegetation (Xu et al., 2005). Thus high percentages of samples with Poaceae probably reflect 'pure' cereal crops, and here can be regarded as a reliable proxy of agricultural activity. The pollen diagram (Figure 2) shows that the percentage of tree pollen is initially high $(37-72 \%)$ with conifers, especially Picea, as the dominant genus. Herbaceous pollen, including Poaceae (about
$1 \%)$, is low in zone $1(5250-5100$ cal. yr BP). In the following zone 2 (5100-4650 cal. yr BP), herbaceous pollen and Poaceae percentage values increase greatly to $21 \%$. Tree pollen, especially conifer values, decreases. After 4650 cal. yr BP conifer values, dominated by Picea, fall from the peak value of $46 \%$ to lower than $1 \%$ while the broadleaved tree taxon of Castanea increases seven fold. Herbaceous taxa, including Artemisia and Polygonaceae, increase to about $77 \%$. Poaceae pollen decreases and Fagopyrum increases between 4650 and 4510 cal. yr BP. Herbaceous pollen ( $88 \%$ ) dominates between 4510 and 4300 cal. yr BP, and Poaceae pollen increases while the rain-fed crop of Fagopyrum showed high percentages (peak value of 30\%) in this episode.

\section{Discussion}

The Xishanping cultural sequence of 5250-4300 cal. yr BP can be divided into two main periods of 5100-4650 cal. yr BP and $4650-4300$ cal. yr BP. These are marked by a rise in Poaceae and the appearance of cereal seeds and phytoliths, then a further expansion of agricultural activity at about 5100 cal. yr BP. Although the high quantities of seeds and phytoliths of millet show the agriculture system was dominated by rain-fed crops, the rice seeds of $5070 \mathrm{cal}$. yr BP together with the continued presence of rice seeds and phytoliths in the whole sequence indicate that rice was already cultivated by 5070 cal. yr BP in northwest China.

The initial appearance of wheat seeds is at about $4650 \mathrm{cal}$. yr BP and continues until 4300 cal. yr BP. Barley and buckwheat were present between 4600 and $4300 \mathrm{cal}$. yr BP. The earliest previously published records of wheat in China are from 2800 BC at Donghuishan at the Hexi corridor of Gansu (Li, 2004), from middle Longshan at about cal. $3600 \mathrm{yr}$ BP at Longshan (Crawford et al., 2005) in central-east China, and from the Gumuguo Culture (2000-1500 BC) of the eastern Tarim Basin in Xinjiang (Thornton and Schurr, 2004). The records of wheat and barley in the Xishanping area given here thus provide the oldest known evidence for their presence in China. Barley has been previously reported from Taosi and 2500-1900 BC (Zhao, 2005). Another important characteristic is that the appearance of wheat, barley and buckwheat coincides with the disappearance of conifers and expansion of chestnut trees, suddenly, at around 4600 cal. yr BP. While this might be related climate change, the sudden and prolonged change is likely to be the result of selective hewing of conifers and cultivation of chestnuts whose fruit was an important food source in ancient China (Luo, 2003). Also farmers may have needed more arable land for crops as population expanded. Fagopyrum probably originated in the highlands of 


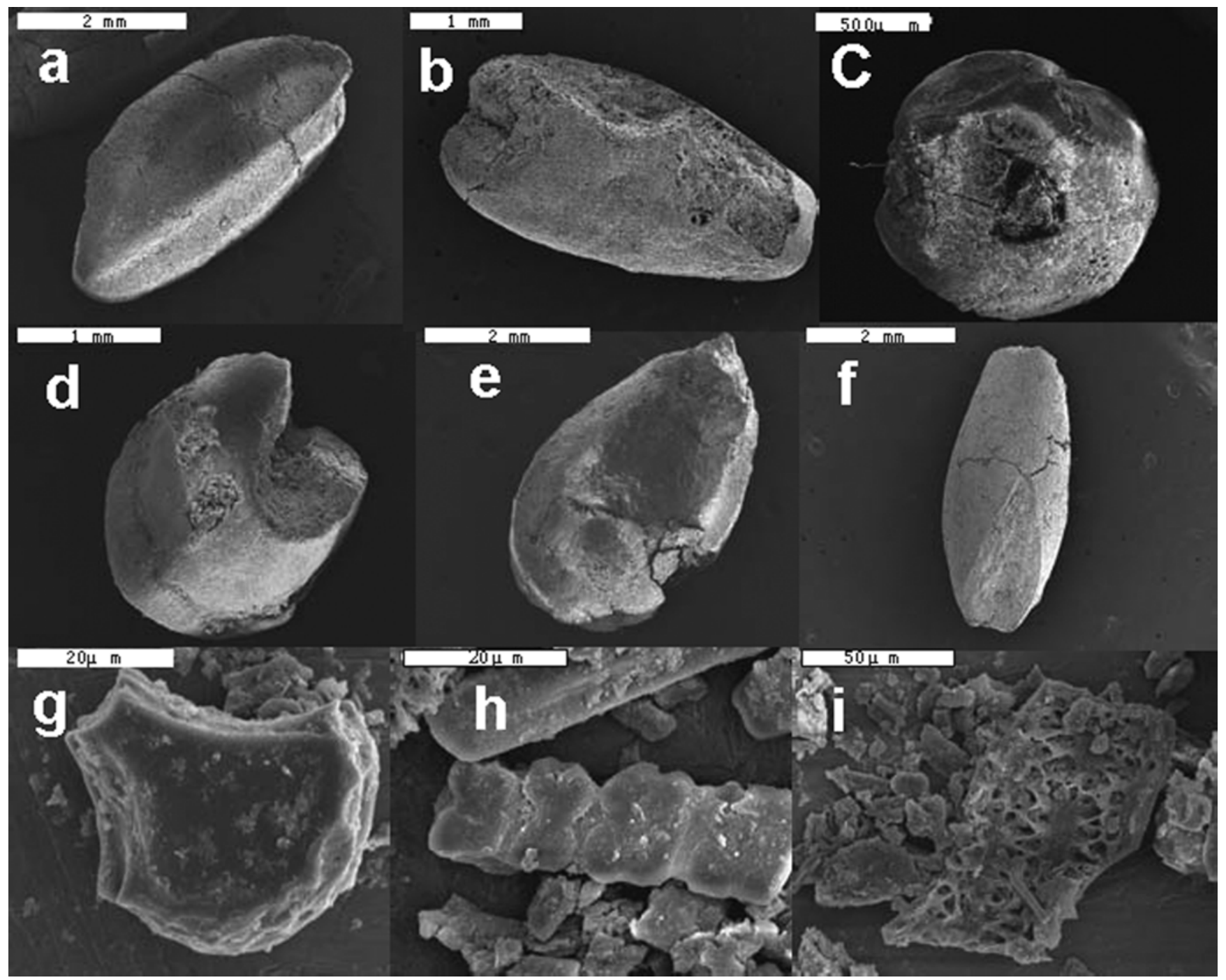

Figure 3 Cereal seeds and phytoliths recovered from Xishanping sediment. (a) Rice seed (Oryza sativa). (b) Wheat seed (Triticum aestivum). (c) Foxtail millet seed (Setaria italica). (d) Broomcorn millet seed (Panicum miliaceum). (e) Barley seed (Hordeum vulgare). (f) Oat seed (Avena sp.). (g) Fan-shaped rice phytolith from leaves. (h) Double-peaked husk rice phytolith. (i) Millet phytolith

Yunnan or in nearby Tibet (Crawford, 2006; Janik, 2002) and it is not otherwise known this early in this part of China. Furthermore, conifer wood was useful for construction and many relics, eg, a multiroom palace occupying an area of 420 $\mathrm{m}^{2}$ has been unearthed and is of this period (the Majiayao cultural period) at Dadiwan near Xishanping (Lang, 2002). It seems that agriculture in the region was probably dominated by rain-fed agriculture of millet and buckwheat; however, Neolithic farmers managed at least eight main crop types of wheat, rice, millet, buckwheat, barley, oats and soybean from 4650 to 4300 cal. yr BP at Xishanping, Tianshui. This complexity suggests a flourishing culture based on agriculture appeared as early as 4650 cal. yr BP in Neolithic northwest China.

Since wheat originated in the west, and rice in the east the coexistence of main crops from West and East is the result of the expansion of plants and/or farming people. The infiltration and blending of agricultural culture between East and West had a profound impact on the formation and development of a complex and broadened agricultural system. The emergence of a complex agriculture can be explained through contact and influence, and not necessarily 'invasions' into middle-late Neolithic northwest China.
We know that agriculture spread to Greece from the Fertile Crescent at about $7000 \mathrm{BC}$ and from Greece to the British Isles over about 2500 years (Harris, 1998; Colledge et al., 2004). Plant-based agriculture reached Pakistan, the Caucasus and Turkmenistan in central Asia between 7000 and $6000 \mathrm{BC}$ (Kushnareva, 1997), and to the Indian subcontinent during 3500-3000 BC (Bellwood, 2001; Fuller, 2005). East Asian agricultural systems were also on the move by this time. There was an overlap area of rice and millet in the middle Yellow River valley of north China in the Yangshao Culture period (Fang et al., 1998) (6800-4900 cal. yr BP, Figure 1). Rice cropping extended south, reaching Thailand and Vietnam in $2300 \mathrm{BC}$, Malaysia and Philippines in 2000 BC (Bellwood, 2005). In the Indian Subcontinent region of the Indus Valley plant-based agriculture was probably present by 2600 BC (Fuller, 2002).

Until now we lacked direct and early evidence to attempt to identify routes through which Neolithic farmers moved and transferred cultural material between East and West Eurasia. The achaeobotanical records from Xishanping provide evidence in this regard. In the expansion of material culture, the lay of the land and climatic conditions played an important role. Because of the obstruction of the Tibet Plateau, the highest land on Earth, and several large deserts such as the 
Taklimakan in northwest China, the exchange of material culture between West, South Asia and China was a difficult process in Neolithic times. Given that the Tianshui Basin is adjacent to the Hexi Corridor of Gansu this lends weight to a natural thoroughfare from West to East Asia via central Asia and through the Tarim Basin or Russian steppes. Considering the time taken for the spread of cultivars in central Asia (7000-6000 BC) and India subcontinent (from 3500 to 3000 BC and later) together with the warm-wet climate in northwest China during 7800-4000 cal. yr BP (An et al., 2005), it is conceivable that Neolithic settlers transferred cultivars to China from southwest Asia via central Asia into northwest China during a favourable climatic period. This spread is about 2500 years earlier than previously thought, and long before the ancient 'Silk Road' route was known to be used in the Han Dynasty (206 BC-AD 220). Cattle and sheep, both derived from the west, are known in central China by 2500-2000 BC (Yuan and Flad, 2005). The timing of the finds reported in this study places the adoption of several cultivars to a much older period than previously thought, and older than the famous Mummies of Ürümchi and the Taklamakam desert (Barber, 1999; Mallory and Mair, 2000).

This raises the intriguing questions as to why crops from China do not appear to have been exchanged westward at this time, and on how cultivated wheat and a flourishing culture based on agriculture contributed to the formation and development of Chinese civilization.

\section{Acknowledgements}

This study was supported by Grants NSFC (40372077, 40572108), Innovation Program of CAS (KZCX3-SW-146) and an Australian Research Council Discovery Grant. We thank Professor Changjiang Liu from Beijing Botany Institute of CAS for identifying crop seeds and Hongli Zhao, Xue Shang for primary field investigation.

\section{References}

Ammerman, A.J. 2003: Looking back. In Ammerman, A.J. and Biagi, P., editors, The widening harvest. Archaeological Institute of America, 3-23.

An, C.B., Tang, L.Y., Barton, L. and Chen, F.H. 2005: Climate change and cultural response around $4000 \mathrm{cal}$ yr BP in the western part of Chinese Loess Plateau. Quaternary Research 63, 347-52.

Armelagos, G.J. and Harper, K.N. 2005: Genomics at the origin of agriculture. Evolutionary Anthropology 14, 109-21.

Barber, E.W. 1999: The Mummies of Ürümchi. W.W. Norton \& Company.

Bellwood, P. 2001: Early agriculturalist population diasporas? Farming, languages, and genes. Annual Review of Anthropology 30, 181-207.

2005: First farmers: the origin of agricultural societies. Blackwell.

Cavalli-Sforza, L., Menozzi, P. and Piazza, A. 1993: Demic expansions and human evolution. Science 259, 639-46.

Colledge, S., Connolly, J. and Shennan, S. 2004: Archaeobotanical evidence for the spread of farming in the eastern Mediterranean. Current Anthropology 45, 35-58.

Crawford, G. 2006: East Asian plant domestication. In Stark, S.T., editor, Archaeology of Asia. Blackwell, 77-95.

Crawford, G., Underhill, A., Zhao, Z.J., Lee, G., Feinman, G., Nicholas, L., Luan, F.S., Yu, H.G., Fang, H. and Cai, F.S. 2005: Late Neolithic plant remains from northern China: preliminary results from Liangchengzhen, Shandong. Current Anthropology 46, 309-17.
Diamond, J. and Bellwood, P. 2003: Farmers and their languages: the first expansions. Science 30, 597-603.

Fang, X.Q., Zhang, W.B. and Zhang, N.S. 1998: The land use arrangement of China in the Holocene megathemal period and its significance. Journal of Natural Resources 13, 16-22.

Fuller, D. 2002: Fifty years of archaeobotanical studies in India: laying a solid foundation. In Settar, S. and Korisettar, R., editors, India Archaeology in Retrospect. Archaeology and Interactive Disciplines 3, 247-363.

2005: Ceramics, seeds and culinary change in prehistoric India. Antiquity 79, 761-77.

Harris, D. 1998: The spread of Neolithic agriculture in Southwest Asia. Review of Archaeology 19, 5-11.

Harvey, E.L. and Fuller, D.Q. 2005: Investigation crop processing using phytolith analysis: the example of rice and millets. Journal of Archaeological Science 32, 739-52.

Hazelwood, L. and Steele, J. 2004: Spatial dynamics of human dispersals: constraints on modelling and archaeological validation. Journal of Archaeological Science 31, 669-79.

Institute of Archaeology of CASS 1999: Shizhaocun and Xishanping. Chinese Encyclopaedia Press.

Janik, L. 2002: Wandering weed: the journey of buckwheat (Fagopyrum sp.) as an indicator of human movement in Eurasia. In Boyle, K., Renfrew, C. and Levine, M., editors, Ancient interactions: east and west in Eurasia. McDonald Institute for Archaeological Research, 299-308.

Kushnareva, O. 1997: The southern Caucasus in Prehistory. University of Pennsylvania.

Lang, S.D. 2002: The primary study on the relics of construction in Dadiwan site. Archaeology and Antiquity 5, 12-17.

Li, S. 2004: On the date of the wheat unearthed at the Donghuishan site, Gansu. Archaeology and Cultural Relics 6, 51-60 (in Chinese). Luo, G.H. 2003: The prehistory domestication of plant and origin of Chinese civilization. Agricultural Archaeology 2003, 64-67 (in Chinese).

Mallory, J.P. and Mair, V.H. 2000: The Tarim Mummies. Thames and Hudson.

Morrell, P.L., Lundy, K.E. and Clegg, M.T. 2003: Distinct geographic patterns of genetic diversity are maintained in wild barley (Hordeum vulgare ssp. spontaneum) despite migration. Proceedings of the National Academy of Sciences, USA 100, 10 812-17.

Shelach, G. 2000: The earliest Neolithic cultures of northeast China: recent discoveries and new perspectives on the beginning of agriculture. Journal of World Prehistory 14, 363-413.

Stuiver, M., Reimer, P.J., Bard, E., Beck, J.W., Burr, G.S., Hughen, A., Kromer, B., McCormac, G., van der Plicht, J. and Spurk, M. 1998: INTCAL 98 radiocarbon age calibration, 24,000-0 cal BP. Radiocarbon 40, 1041-83.

Thornton, C.P. and Schurr, T.G. 2004: Genes, language, and culture: an example from the Tarim Basin. Oxford Journal of Archaeology 23, 83-106.

Underhill, A. 1997: Current issues in Chinese Neolithic archaeology. Journal of World Prehistory 11, 103-60.

Wilcox, G. 2005: The distribution, natural habits and availability of wild cereals in relation to their domestication in the Near East: multiple events, multiple centres. Journal of Vegetation History and Archaeobotany 14, 534-41.

Wu, Z.Y. and Wang, H.S. 1983: Botanical geography. Science Press. Xu, Q.H., Li, Y.C. and Yang, X.L. 2005: The analysis of surface pollen in the main groups in grassland, North China. Geological Research 24, 394-402.

Yuan, J. and Flad, R. 2005: New zooarchaeological evidence for changes in Shang Dynasty animal sacrifice. Journal of Anthropological Archaeology 24, 252-70.

Zhao, Z. 1998: The Middle Yangtze region in China is one place where rice was domesticated. Antiquity 72, 885-96. 2005: Palaeoethnobotany and its new achievements in China. Archaeology and Cultural Relics 7, 42-49 (in Chinese).

Zohary, D. and Hopf, M. 2000: Domestication of plants in the old world. Oxford University Press. 